http://dx.doi.org/10.18778/1509-877X.02.04

\title{
KONSTRUKCJA PODATKU OD NIERUCHOMOŚCI A ZASADY PRAWIDŁOWEJ LEGISLACJI
}

\begin{abstract}
Streszczenie. Artykuł porusza kwestie przestrzegania przez ustawodawcę zasad prawidłowej legislacji przy tworzeniu podstawowych elementów konstrukcyjnych podatku od nieruchomości. Podjęta tematyka ma doniosłe znaczenie zarówno w odniesieniu do organów stosujących prawo jak i względem podatnika zobowiązanego niejednokrotnie do dokonania samoobliczenia. Nieprzestrzeganie zasad prawidłowej legislacji przy kreacji elementów konstrukcyjnych podatku skutkuje licznymi kontrowersjami interpretacyjnymi, które przekładają się na powstawanie sporów na linii organ - podatnik, stosowanie środków przymusu względem podatnika czy też na efektywność danego źródła dochodowego. Dlatego też omawiana problematyka jest szczególnie istotna dla finansów komunalnych. Podatek od nieruchomości stanowi bowiem jedno z najważniejszych źródeł podatkowych gmin w Polsce.
\end{abstract}

Słowa kluczowe: podatek od nieruchomości, zasady prawidłowej legislacji, konstrukcja podatku od nieruchomości, problemy interpretacyjne

1. WSTĘP

Podatek od nieruchomości jest daniną, której wpływy zasilają budżety gmin w sposób najbardziej wydajny w porównaniu do pozostałych podatków komunalnych ${ }^{1}$. Mimo to powstaje pytanie, czy jego obecna

*Uniwersytet Łódzki, Wydział Prawa i Administracji, Katedra Prawa Finansowego.

${ }^{1}$ Według danych PWC średni udział tego podatku $\mathrm{w}$ dochodach gmin $\mathrm{w}$ latach 2011-2015, z tytułu podatków lokalnych wynosił aż 83\%. Natomiast udział podatku od nieruchomości w całości dochodów gmin $\mathrm{z}$ tytułu podatków wynosił w tym okresie średnio 33\%, https://www.pwc.pl/pl/pdf/25-lat-podatku-od-nieruchomosci-w-polsce-raport-pwc.pdf (dostęp: 3.05.2018). 
konstrukcja pozwala na uzyskiwanie dochodu w sposób najbardziej efektywny, czy też skutkuje obniżeniem wydajności tego źródła dochodowego. Powyższa wątpliwość jest związana z problemami interpretacyjnymi, które dotyczą w szczególności przepisów regulujących podstawowe elementy konstrukcyjne ww. daniny, jak przykładowo przedmiot opodatkowania czy też zwolnienia.

Wątpliwości interpretacyjne co do tak podstawowych elementów konstrukcji podatku rodzą pytanie, czy można postawić ustawodawcy zarzut naruszenia zasad prawidłowej legislacji. Nieprzestrzeganie zasad prawidłowej legislacji przez ustawodawcę nie tylko wpływa niekorzystnie na kondycję finansową gmin, lecz również na sytuację podatnika. Podatnik, niejednokrotnie zobowiązany do dokonania samoobliczenia, ma prawo oczekiwać od ustawodawcy tworzenia czytelnych zasad opodatkowania oraz na tyle jasnych przepisów aby nie powstawały kontrowersje przy obliczaniu na ich podstawie właściwej kwoty podatku. Dzięki prawidłowej legislacji zmniejsza się prawdopodobieństwo powstawania sporu pomiędzy podatnikiem a organem podatkowym, a nadto, skutkiem jej zastosowania jest umożliwienie podatnikowi wykonania, w sposób prawnie wymagany, zobowiązania podatkowego i uniknięcia zastosowania względem niego środków przymusu².

Celem niniejszego artykułu jest identyfikacja tych unormowań kształtujących konstrukcję podatku od nieruchomości, których sposób sformułowania zdaje się naruszać zasady prawidłowej legislacji.

\section{ZASADY PRAWIDŁOWEJ LEGISLACJI}

Zasady prawidłowej legislacji można definiować jako „sui generis zbiór reguł i zasad podlegający ewolucyjnym modyfikacjom zarówno pod względem ilościowym jak również znaczeniowym. Każda z zasad prawidłowej legislacji została wyprowadzona $\mathrm{z}$ istoty demokratycznego państwa prawnego" 3 . Inna definicja wskazuje, że są to „dyrektywy o dużym stopniu ogólności, adresowane do podmiotów tworzących prawo i wskazujące tym podmiotom, jak powinny one rozstrzygać poszczególne problemy nasuwające się $\mathrm{w}$ związku z tworzeniem prawa oraz jak ukształtować proces

${ }^{2}$ J. Glumińska-Pawlic, Podatki i opłaty lokalne: małe podatki - duże absurdy, [w:] Absurdy polskiego prawa podatkowego. Teoria i praktyka, t. VI, Katowice 2012, s. 69.

${ }^{3}$ J. Zaleśny, Zasady prawidłowej legislacji, „Studia i Analizy” 2009, t. 13, s. 14. 
tworzenia prawa, aby problemy te mogły zostać rozwiązane w sposób należyty" ${ }^{4}$. W wyroku z dnia 25 listopada 1997 r. Trybunał Konstytucyjny wyjaśnił, że zasada prawidłowej legislacji „stanowi swojego rodzaju zbiorcze wyrażenie szeregu reguł i zasad, które wprawdzie nie zostały expressis verbis ujęte $\mathrm{w}$ pisanym tekście konstytucji, ale w sposób immamentny wynikają $\mathrm{z}$ aksjologii oraz $\mathrm{z}$ istoty demokratycznego państwa prawnego. [...]"5. Doniosłość zasad prawidłowej legislacji przejawia się w możliwości uchylenia przepisu prawnego w oparciu o kwalifikowane naruszenie danej zasady. Chociaż, niektórzy autorzy dokonali wyodrębnienia aż 31 zasad prawidłowej legislacji ${ }^{6}$, to najczęściej opisywanymi spośród nich są: zasada dookreśloności przepisów prawnych, niedziałania prawa wstecz, ochrony praw nabytych oraz odpowiedniego vacatio legis.

\section{ZASADA DOOKREŚLONOŚCI PRZEPISÓW PRAWNYCH}

\section{A PODATEK OD NIERUCHOMOŚCI}

Zgodnie z zasadą dookreśloności przepisów prawnych ustawodawca powinien tak formułować przepisy, aby były one jasne i zrozumiałe. W sposób szczególny zasada ta odnosi się do przepisów prawa podatkowego z uwagi na fakt nałożenia na podatnika nie tylko obowiązku zapłaty podatku, lecz również jego samowymiaru, za realizacje których to obowiązków podatnik ponosi odpowiedzialność o obiektywnym charakterze. Obowiązek znajomości prawa w stopniu właściwym dla organów podatkowych obciążający podatnika wymaga, aby przepisy podatkowe były komunikatywne oraz formułowanie w sposób poprawny językowo. „Jednocześnie podnosi się, że komunikatywności tej nie osiągnie się, stosując nadmiernie i w sposób nieuzasadniony technikę rozczłonkowania norm, co przejawia się rozproszeniem elementów składających się na daną normę prawną"7.

Komunikatywność przepisu prawnego zostaje niwelowana poprzez odsyłanie do innych przepisów, nie tylko znajdujących się w danej ustawie

${ }^{4}$ A. Michalska, S. Wronkowska, Zasady tworzenia prawa, Poznań 1983, s. 55, podaje za: S. Bułajewski, Zasady prawidłowej legislacji podczas tworzenia aktów prawa miejscowego $w$ Polsce, „Studia Prawnoustrojowe” 2015, nr 29, s. 31-42.

${ }^{5}$ Sygn. akt K 26/97, OTK 1997, nr 5-6, poz. 64.

${ }^{6}$ H. Rot, Ogólne zasady tworzenia prawa PRL, „Studia Prawnicze” 1978, nr 4, s. 33, podaję za: S. Bułajewski, Zasady prawidłowej legislacji podczas tworzenia aktów..., s. 31-42.

${ }^{7}$ D. Mączyński, R. Sowiński, Jasność prawa podatkowego jako warunek poprawnej legislacji podatkowej, „Ruch Prawniczy, Ekonomiczny i Socjologiczny” 2005, z. 3, s. 37. 
podatkowej, ale również do aktów wywodzących się z innych gałęzi prawa. $Z$ jednej strony technika odsyłania do aktów spoza danej gałęzi może być uzasadniania jednolitością systemu prawnego, z drugiej naraża jednak podatnika na znacznie utrudnioną subsumpcję podatkowej normy prawnej, na którą składają się przepisy z ustaw „niepodatkowych” co do których wymóg precyzyjności jest znacznie mniejszy, i których zrozumienie niejednokrotnie wymaga specjalistycznej wiedzy. Niedookreśloność przepisów podatkowych stanowi oczywiście także utrudnienie w procesie wykładni dla organów stosujących prawo. Istotne wątpliwości interpretacyjne co do podstawowych elementów konstrukcyjnych podatków nie sprzyjają stabilności tych źródeł dochodów budżetowych, co z kolei może mieć wpływ na efektywność wykonywania zadań publicznych przez podmioty publiczne.

Przechodząc do przykładów braku dookreśloności przepisów normujących podatek od nieruchomości wskazać należy na brak precyzyjnej definicji budowli na gruncie ustawy o podatkach i opłatach lokalnych ${ }^{8}$. Do roku 2003 podatnik, aby odkodować to pojęcie musiał sięgać do słownika języka polskiego. Od roku 2003 ustawodawca odesłał podatnika interpretującego ten termin do definicji budowli zawartej w Prawie budowlanym ${ }^{9}$, co wcale nie zakończyło kontrowersji. Ustawa Prawo budowlane cechuje się innymi standardami konstytucyjnymi niż ustawa podatkowa ${ }^{10}$. Przede wszystkim chodzi o niedookreśloność niektórych pojęć użytych na gruncie tej ustawy, co z punktu widzenia art. 217 Konstytucji RP ${ }^{11}$ jest niedopuszczalne w nomenklaturze ustawy podatkowej, która powinna charakteryzować się wysokim stopniem szczegółowości. Podatnik zgodnie z powyższym artykułem musi mieć pewność co do wszystkich elementów konstrukcyjnych podatku. Powyższa wadliwość konstrukcji podatku od nieruchomości powoduje, że podatek ten staje się mniej wydajny i naraża samorząd na straty dochodowe. Jeden $\mathrm{z}$ ostatnich wyroków Trybunału Konstytucyjnego o sygn. SK 48/15 z dnia 13 grudnia $2017^{12}$, dotyczący analizy zgodności

${ }^{8}$ Ustawa z dnia 12 stycznia 1991 r. o podatkach i opłatach lokalnych (tj. Dz.U. z 2017 r., poz. 1785).

${ }^{9}$ Ustawa z dnia 7 lipca 1994 r. Prawo budowlane (tj. Dz.U. z 2017 r., poz. 1332).

${ }^{10} \mathrm{http}$ ://phavi.umcs.pl/at/attachments/2016/0407/053948-25-lat-podatkow-raport.pdf (dostęp: 3.05.2018).

${ }^{11}$ Konstytucja Rzeczypospolitej Polskiej z dnia 2 kwietnia 1997 r. (Dz.U. z 2009 r. Nr 114, poz. 946).

${ }^{12}$ Wyrok Trybunału Konstytucyjnego z dnia 13 grudnia 2017, sygn. SK 48/15 (Dz.U. z 2017 r., poz. 2432). 
ustalania podstawy opodatkowania podatkiem od nieruchomości z Konstytucją RP, z wysokim stopniem prawdopodobieństwa będzie podstawą do zwrotu nadpłaty podatku od nieruchomości.

Zawyżenie podstawy opodatkowania powstało z uwagi na to, że przepisy ustawy o podatkach i opłatach lokalnych, pozwoliły na taką interpretację, ustaloną jednolicie zarówno przez sądy administracyjne jak i organy lokalne, zgodnie z którą obiekt budowlany spełniający wszystkie cechy budynku wymienione $\mathrm{w}$ art. 1a ust. 1 pkt 1 ustawy o podatkach i opłatach lokalnych, był

uznawany za budowlę w oparciu o dodatkowe, niewskazane w ustawie o podatkach i opłatach lokalnych kryteria (takie jak np. jego przeznaczenie, funkcje, wyposażenie, oraz sposób i możliwość wykorzystania budynku). Następstwem takiej wykładni było zastosowanie do obiektów wyczerpujących definicję budynku zasad określania wysokości zobowiązania podatkowego w sposób właściwy dla obiektów stanowiących budowle, w wyniku czego dochodziło do bezpodstawnego zwielokrotnienia kwoty zobowiązania w podatku od nieruchomości ${ }^{13}$.

Przypomnijmy, budynek zgodnie art. 1a ust. 1 pkt 1 i 2 ustawy o podatkach i opłatach lokalnych oznacza obiekt budowlany w rozumieniu przepisów prawa budowlanego, który jest trwale związany z gruntem, wydzielony z przestrzeni za pomocą przegród budowlanych oraz posiada fundamenty i dach. Budowla natomiast zgodnie $\mathrm{z}$ art.1a pkt 2 ustawy o podatkach i opłatach lokalnych jest obiektem budowlanym w rozumieniu przepisów prawa budowlanego niebędącym budynkiem lub obiektem małej architektury, a także urządzeniem budowlanym w rozumieniu przepisów prawa budowlanego związanym z obiektem budowlanym, który zapewnia możliwość użytkowania obiektu zgodnie z jego przeznaczeniem.

$\mathrm{Z}$ kolei zgodnie $\mathrm{z}$ art. 3 pkt 3 ustawy Prawo budowlane przez budowlę należy rozumieć każdy obiekt budowlany niebędący budynkiem lub obiektem małej architektury, jak: obiekty liniowe, lotniska, mosty, wiadukty, estakady, tunele, przepusty, sieci techniczne, wolno stojące maszty antenowe, wolno stojące trwale związane $\mathrm{z}$ gruntem tablice reklamowe i urządzenia reklamowe, budowle ziemne, obronne (fortyfikacje), ochronne, hydrotechniczne, zbiorniki, wolno stojące instalacje przemysłowe lub urządzenia techniczne, oczyszczalnie ścieków, składowiska odpadów, stacje uzdatniania wody, konstrukcje

13 http://trybunal.gov.pl/postepowanie-i-orzeczenia/komunikaty-prasowe/komunikaty-przed/art/9962-podatki-i-oplaty-lokalne-zasady-ustalania-podatku-od-nieruchomosci/ (dostęp: 3.05.2018). 
oporowe, nadziemne i podziemne przejścia dla pieszych, sieci uzbrojenia terenu, budowle sportowe, cmentarze, pomniki, a także części budowlane urządzeń technicznych (kotłów, pieców przemysłowych, elektrowni jądrowych i innych urządzeń) oraz fundamenty pod maszyny i urządzenia, jako odrębne pod względem technicznym części przedmiotów składających się na całość użytkową. Zarówno sądy administracyjne jak również organy podatkowe opierały swoją argumentację m.in. na założeniu, iż skoro „ustawodawca nie zastrzegł w definicji pojęcia budynku warunku, iż nie może on być budowlą, czyniąc jedynie zastrzeżenie w definicji pojęcia budowli, iż nie może być ona budynkiem, to nie jest wykluczone, by pewne budynki uznać za budowle”. Trybunał odrzucił powyższe stanowisko $\mathrm{z}$ uwagi na fakt, iż „definicja pojęcia budowli, zawarta zarówno w prawie budowlanym, jak i w ustawie o podatkach lokalnych, przewiduje jednoznacznie, że budowlą jest obiekt budowlany niebędący budynkiem lub obiektem małej architektury". Trudności interpretacyjne w zakresie przedmiotu opodatkowania występują również w kontekście przenośnych kontenerów, wykorzystywanych przez przedsiębiorstwa budowlane. $\mathrm{O}$ ile nie są one desygnatem pojęcia budynek, bowiem nie występuje $\mathrm{w}$ ich przypadku trwale związane z gruntem, o tyle organy podatkowe wielokrotnie uznawały, że stanowią one budowlę w rozumieniu art. 3 pkt 3 ustawy Prawo budowlane $\mathrm{w}$ zw. $\mathrm{z}$ art. 1a pkt 2 ustawy o podatkach i opłatach lokalnych. Organy podatkowe, mimo braku wymienienia $\mathrm{w}$ ww. artykule kontenerów uznawały, że są one budowlą. W ocenie Naczelnego Sądu Administracyjnego jest to błędna interpretacja. W uchwale z dnia 3 lutego 2014 r., o sygn. akt: II FPS 11/13, Naczelny Sąd Administracyjny stwierdził, że:

Precyzyjnie ujmując, z punktu widzenia standardów konstytucyjnych nie sposób zaakceptować sytuację, gdy jako przedmiot opodatkowania podatkiem od nieruchomości byłyby traktowane budowle w rozumieniu art. 3 pkt 3 P.b. nienależące do kategorii obiektów, które expressis verbis wymieniono w tym przepisie (lub - co wynika z wcześniejszych ustaleń - w pozostałych przepisach rozważanej ustawy albo w załączniku do niej), lecz będące obiektami jedynie do nich podobnymi ${ }^{14}$.

Należy zauważyć, że obiekty kontenerowe zostały wymienione jako desygnat tymczasowego obiektu budowlanego w art. 3 pkt 5 ustawy Prawo budowlane. Zgodnie $\mathrm{z}$ art. 2 ust. 1 ustawy o podatkach i opłatach lokalnych, tymczasowe obiekty budowlane nie są opodatkowane podatkiem od nieruchomości, chyba że spełniają warunki definicyjne budynku albo budowli.

${ }^{14}$ Uchwała Naczelnego Sądu Administracyjnego z dnia 3 lutego 2014 r., o sygn. akt: II FPS 11/13, http://orzeczenia.nsa.gov.pl/doc/85A6A45719 (dostęp: 3.05.2018). 
Problem niedookreśloności przepisów w podatku od nieruchomości widoczny jest również w przypadku regulacji obejmującej zwolnienia. W literaturze jako przykład wskazuje się niejasność przepisów odnoszących się do zwolnienia infrastruktury kolejowej uregulowanego $\mathrm{w}$ art. 7 ust. 1 pkt 1 ustawy o podatkach i opłatach lokalnych. Ustawodawca wielokrotnie podejmował próby sanacji powyższego przepisu, jednak nie można ich uznać za satysfakcjonujące. Przykładowo w roku 2006 wprowadzono zmianę, której uzasadnieniem było usunięcie wątpliwości interpretacyjnych związanych z wyrażeniem „publiczny transport kolejowy”. Zgodnie bowiem z ówczesnym brzmieniem art. 7 ust. 1 pkt 1 ww. ustawy od podatku zwolnione były budowle kolejowe stanowiące całość techniczno-użytkową wraz z instalacjami i urządzeniami, służące do ruchu pojazdów kolejowych, organizacji i sterowania tym ruchem, umożliwiając dokonywanie przewozów osób lub rzeczy - wykorzystywane wyłącznie na potrzeby publicznego transportu kolejowego, a także zajęte pod nie grunty. Po nowelizacji wolą ustawodawcy zwolniono budowle wchodzące w skład infrastruktury kolejowej w rozumieniu przepisów o transporcie kolejowym oraz zajęte pod nie grunty jeżeli:

a) zarządca infrastruktury jest obowiązany do jej udostępniania licencjonowanym przewoźnikom kolejowym lub

b) są przeznaczone wyłącznie do przewozu osób, wykonywanego przez przewoźnika kolejowego, który równocześnie zarządza tą infrastrukturą bez udostępniania jej innym przewoźnikom, lub

c) tworzą linie kolejowe o szerokości torów większej niż $1435 \mathrm{~mm}$.

Ustawodawca nie zdecydował się zatem na zdefiniowanie wyrażenia publicznego transportu kolejowego. W nowym brzmieniu przepisu powyższe wyrażenie zastąpił nowym pojęciem tj. infrastrukturą kolejową zdefiniowaną na gruncie ustawy o transporcie kolejowym ${ }^{15}$. Do tej definicji ustawodawca odsyła podatnika. Należy jednak zauważyć, że w komentowanym przepisie występują również inne pojęcia, których definicje znajdują się w ustawie o transporcie kolejowym jak przykładowo „zarządca infrastruktury”, „przewoźnik kolejowy” czy „linie kolejowe”. Mimo to ustawodawca w tym zakresie nie dokonał stosownego odesłania ani też nie zdefiniował powyższych pojęć na gruncie ustawy o podatkach i opłatach lokalnych, co mogło stanowić przyczynek wątpliwości interpretacyjnych ${ }^{16}$.

${ }^{15}$ Ustawa z dnia 28 marca 2003 r. o transporcie kolejowym (Dz.U. z 2003 r. Nr 86, poz. 789).

${ }^{16}$ https://ikar.wz.uw.edu.pl/numery/21/pdf/94.pdf (dostęp: 6.06.2018). 
Odesłanie do ustawy o transporcie kolejowym w zakresie podstawowego dla zastosowania zwolnienia pojęcia spowodowało liczne wątpliwości chociażby w zakresie opodatkowania bocznicy kolejowej. Podstawowym pytaniem w tym przypadku było czy bocznica kolejowa wchodzi w skład infrastruktury kolejowej.

Zgodnie $\mathrm{z}$ art. 4 pkt 1 ustawy o transporcie kolejowym w brzmieniu obowiązującym do roku 2017 infrastruktura kolejowa to linie kolejowe oraz inne budowle, budynki i urządzenia wraz z zajętymi pod nie gruntami, usytuowane na obszarze kolejowym, przeznaczone do zarządzania, obsługi przewozu osób i rzeczy, a także utrzymania niezbędnego $\mathrm{w}$ tym celu majątku zarządcy infrastruktury. $\mathrm{Z}$ kolei zgodnie $\mathrm{z}$ art. 4 pkt 2 tejże ustawy linią kolejową jest droga kolejowa mająca początek i koniec wraz z przyległym pasem gruntu, na którą składają się odcinki linii, a także budynki, budowle i urządzenia przeznaczone do prowadzenia ruchu kolejowego wraz z zajętymi pod nie gruntami. Z definicji linii kolejowej ciężko jest sformułować odpowiedź dotyczącą charakteru bocznicy kolejowej ${ }^{17}$.

Z jednej strony orzecznictwo sądów administracyjnych przyjmowało, że bocznice kolejowe nie są częścią linii kolejowych, ponieważ w istocie, zgodnie $\mathrm{z}$ definicją zawartą w ustawie o transporcie kolejowym, są drogami kolejowymi połączonymi z linią kolejową i w związku z powyższym nie są objęte zwolnieniem z podatku od nieruchomości (tak przykładowo wyrok NSA z 22 sierpnia 2012 r., II FSK 130/11). Jak opisują A. Kałążny oraz M. Ruta głównym powodem przyjmowania powyższego stanowiska był brak wskazania przez ustawodawcę w przepisach ustawy o transporcie kolejowym, iż bocznice kolejowe stanowią element infrastruktury kolejowej.

Ponadto zgodnie z art. 7 ust. 1 pkt 1 lit. a) u.p.o.l. w brzmieniu obowiązującym przed 1.01.2017 r. zwolnieniu podlegały budowle infrastruktury kolejowej, jeśli zarządca infrastruktury był obowiązany do ich udostępniania licencjonowanym przewoźnikom kolejowym. Tymczasem zgodnie z przepisami ustawy o transporcie kolejowym zarządca infrastruktury nie był i nie mógł być zobowiązany do udostępniania bocznicy kolejowej przewoźnikom kolejowym, chociażby z tego względu, że na gruncie tej ustawy „użytkownik bocznicy” $i$,zarządca infrastruktury kolejowej” były rozłącznymi pojęciami ${ }^{18}$.

Z drugiej strony, w innych orzeczeniach został zaaprobowany odmienny pogląd zgodnie z którym bocznica kolejowa była elementem infrastruktury kolejowej (por. wyrok NSA z dnia 22 października 2013 r.,

17 Tamże.

${ }^{18}$ A. Kałążny, M. Ruta, Bocznica kolejowa jako element infrastruktury kolejowej - czy podlega zwolnieniu z podatku od nieruchomości?, „Przegląd Podatkowy” 2018, nr 1, s. 37-42. 
sygn. akt II OSK 1224/12 ${ }^{19}$, wyrok NSA z dnia 22 sierpnia 2012 r., sygn. akt II FSK 130/1120). Dopuszczalność tej kwalifikacji wynikała, po pierwsze, z możliwości zakwalifikowania bocznicy kolejowej jako innych budowli, budynków i urządzeń wraz z zajętymi pod nie gruntami, usytuowanych na obszarze kolejowym, przeznaczonych do zarządzania, obsługi przewozu osób i rzeczy, które stanowią desygnat infrastruktury kolejowej ${ }^{21}$. Po drugie, przemawiała za tym wykładnia historyczna: „W stanie prawnym obowiązującym przed dniem 2 listopada 2007 r. bocznica kolejowa była w ustawie o transporcie kolejowym określana wprost jako infrastruktura kolejowa, a od tamtego czasu definicja samej infrastruktury kolejowej nie uległa zmianie"22.

Powyżej opisany problem został usunięty poprzez nowelizację ustawy o transporcie kolejowym, która zaczęła obowiązywać od stycznia 2017 r. Ustawodawca expresis verbis wskazał, iż bocznica kolejowa stanowi infrastrukturę kolejową. Zgodnie bowiem z treścią Załącznika nr 1 do ww. ustawy, który stanowi wykaz elementów infrastruktury kolejowej, w skład infrastruktury kolejowej wchodzą wymienione w powyższym załączniku elementy, pod warunkiem że tworzą część linii kolejowej, bocznicy kolejowej lub innej drogi kolejowej, lub są przeznaczone do zarządzania nimi, obsługi przewozu osób lub rzeczy, lub ich utrzymania.

Jednocześnie jednak, ustawodawcy nie udało się ominąć innych niedookreśleń. Dla ustalenia zakresu zwolnienia w podatku od nieruchomości problematyczne może okazać się prawidłowe ustalenie desygnatów pojęć wymienionych jako elementy nowej definicji infrastruktury kolejowej. Jako przykład może posłużyć pkt 6 Załącznika nr 1 do ustawy o transporcie kolejowym. Zgodnie z powyższą regulacją w skład infrastruktury kolejowej wchodzą perony „wraz z infrastrukturą umożliwiającą dotarcie do nich pasażerom, pieszo lub pojazdem, z drogi publicznej lub dworca kolejowego. Ministerstwo Finansów w toku prac nad przedmiotową nowelizacją „wskazywało, że z zapisu tego nie wynika jednoznacznie, czym są wymienione obiekty i które $z$ nich nie powinny być opodatkowane lub

${ }^{19}$ http://orzeczenia.nsa.gov.pl/doc/3BB24DD209 (dostęp: 6.06.2018).

${ }^{20} \mathrm{http}$ //orzeczenia.nsa.gov.pl/doc/F4ADB9405A (dostęp: 6.06.2018).

${ }^{21}$ B. Brzeziński, K. Lasiński-Sulecki, W. Morawski, Relacje terminologiczne ustawy podatkowej i „niepodatkowej” - kazus zwolnienia z podatku od nieruchomości infrastruktury kolejowej, „Przegląd Podatkowy” 2013, nr 5, s. 16-24.

${ }^{22}$ http://orzeczenia.nsa.gov.pl/doc/B846A5F30B (dostęp: 6.06.2018). 
zwolnione" 23 . Przepisy art. 7 ust. 1 pkt 1 ustawy o podatkach i opłatach lokalnych w związku z regulacją ustawy o transporcie kolejowym nadal są w sposób znaczący „niejednoznaczne i nie widać tu istotnej poprawy w stosunku do stanu sprzed ich nowelizacji. Jedne problemy interpretacyjne zostały ponownie zastąpione przez inne"24.

\section{ZASADA ODPOWIEDNIEGO VACATIO LEGIS A ZMIANY} W PODATKU OD NIERUCHOMOŚCI

Zasady prawidłowej legislacji ustaw podatkowych nakazują w zakresie procedury legislacyjnej, aby wszelkie zmiany w zakresie opodatkowania nie następowały nagle i co do zasady nie były dokonywane w trakcie trwania roku podatkowego. W wyrokach Trybunału Konstytucyjnego powyżej zarysowana dyrektywa jest traktowana jako

uszczegółowienie, $\mathrm{w}$ odniesieniu do prawa daninowego, zasady zaufania obywatela do państwa i stanowionego przez nie prawa oraz ochrony bezpieczeństwa prawnego (zob. wyrok TK z 15 lipca 2013 r., sygn. K 7/12). Zakaz ten jest „zabezpieczeniem możliwości rozporządzania przez jednostkę swoimi interesami życiowymi przy uwzględnieniu regulacji podatkowych opublikowanych i znanych podatnikowi jeszcze przed rozpoczęciem roku podatkowego" (wyrok TK z 25 kwietnia 2001 r., sygn. K 13/01, OTKZU nr 4/2001, poz. 81). Jednocześnie należy podkreślić, że zakaz wprowadzania zmian prawnych w czasie trwania roku podatkowego dotyczy wszystkich podatków, w których wymiar podatku dokonywany jest za okresy roczne (zob. wyrok TK z 15 lutego 2005 r., sygn. K 48/04, OTK ZU nr 2/A/2005, poz. 15). W orzecznictwie Trybunału brak jest wprawdzie ogólnej definicji pojęcia „podatek rozliczany w skali rocznej", ale w tym zakresie można odwołać do typowych cech podatku dochodowego od osób fizycznych i uznać, że jest to, po pierwsze, podatek wymierzany od sumy dochodów uzyskanych w ciągu roku podatkowego, bez względu na to, którego dnia tego roku dochody wpłynęły do podatnika; i że, po drugie, rozliczenie tego podatku może nastąpić dopiero w następnym roku kalendarzowym (zob. sygn. K 7/12). To właśnie ze względu na opisany sposób rozliczania takiego podatku podatnik nie powinien być zaskakiwany zmianami $\mathrm{w}$ trakcie trwania roku podatkowego, $\mathrm{z}$ reguły zbieżnego $\mathrm{z}$ rokiem kalendarzowym ${ }^{25}$.

${ }^{23}$ http://podatki.gazetaprawna.pl/artykuly/994969,transport-kolejowy-podatek-od-budynkow-gruntow-infrastruktura-kolejowa.html (dostęp: 6.06.2018).

${ }^{24}$ B. Brzeziński, K. Lasiński-Sulecki, W. Morawski, Relacje terminologiczne ustawy podatkowej $i$ „niepodatkowej”..., s. 16-24.

${ }^{25}$ Wyrok Trybunału Konstytucyjnego z dnia 18 listopada 2014 r. Sygn. akt K 23/12, (Dz.U. z 2014 r., poz.1663). 
Powyższa zasada nie ma charakteru absolutnego - istnieje możliwość odstąpienia od niej, o ile przemawiają za tym uzasadnione argumenty prawne (tak też sygn. K 13/01). „Również w doktrynie prawa wyrażany jest pogląd, zgodnie z którym w ciągu roku kalendarzowego można dokonywać modyfikacji dotyczących danin publicznych, które nie są pobierane w skali rocznej (zob. A. Krzywoń, op. cit., s. 14-149)"26. Reguła zakazująca wprowadzania zmian w podatkach rocznych w ciągu roku podatkowego odnosi się do wszystkich elementów konstrukcyjnych obowiązku podatkowego, a zatem do podmiotu, przedmiotu, podstawy opodatkowania oraz stawek podatkowych.

Zasadniczym pytaniem staje się zatem, czy podatek od nieruchomości jest podatkiem rocznym.

Analiza przepisów ustawy o podatkach i opłatach lokalnych pozwala na ustalenie rocznego charakteru podatku od nieruchomości. Okresem podatkowym w podatku od nieruchomości jest rok kalendarzowy. O powyższym stanowi chociażby art. 6 ust. 5 ustawy o podatkach i opłatach lokalnych, w brzmieniu następującym: W przypadku, gdy obowiązek podatkowy powstał w trakcie roku podatkowego zobowiązanie podatkowe za ten rok ustala się proporcjonalnie do liczby miesięcy, w których istniał obowiązek podatkowy. Zgodnie $\mathrm{z}$ art. 5 ust.1 ustawy o podatkach i opłatach lokalnych rada gminy ustala stawki w podatku od nieruchomości, które są ograniczane rocznie. Zgodnie $\mathrm{z}$ art. 7 ww. ustawy rada gminy określa w drodze decyzji podatek od nieruchomości na rok podatkowy. Art. 8a wskazuje, że nie wszczyna się postępowania a wszczęte umarza, jeżeli wysokość zobowiązania podatkowego na dany rok podatkowy nie przekraczałaby określonych na dzień 1 stycznia roku podatkowego kosztów doręczenia w obrocie krajowym przesyłki poleconej za potwierdzeniem odbioru przez operatora w rozumieniu ustawy Prawo Pocztowe ${ }^{27}$.

Pomimo rocznego charakteru podatku od nieruchomości, odesłanie $\mathrm{w}$ zakresie dookreślenia podstawy opodatkowania $\mathrm{w}$ tym podatku do innych ustaw niepodatkowych powoduje, że zmiana ta może nastąpić w trakcie roku podatkowego. Przykładowo, nowelizacja Prawa budowlanego z 20 lutego 2015 r., wprowadzająca istotne zmiany w zakresie definicji budowli i budynku weszła w życie 28 czerwca 2015 roku co oznaczało, że

${ }^{26}$ Tamże.

${ }^{27}$ Ustawa z dnia 23 listopada 2012 r. Prawo pocztowe (Dz.U. z 2012 r., poz. 1529 z późń. zm.). 
ingerowała w rozliczenie podatku od nieruchomości już od lipca 2015 r. $^{28}$ Warto również wskazać, że omawiana zasada adresowana jest także do organów gminy, które, w sposób ograniczony ustawą, posiadają wąski zakres władztwa odnośnie uchwalania wysokości stawek w podatku od nieruchomości oraz zwolnień przedmiotowych. Zgodnie z tą zasadą Rada Gminy nie może w trakcie roku podatkowego podjąć uchwały o zniesieniu danego zwolnienia przedmiotowego.

Regionalna Izba Obrachunkowa w Zielonej Górze w uchwale nr 159/09 z dnia 5 sierpnia 2009 r. $^{29}$, w sprawie dotyczącej cofnięcia zwolnienia z podatku od nieruchomości 50\% powierzchni gruntów i budynków stanowiących własność osób powyżej 65. roku życia prowadzących samodzielnie gospodarstwo domowe, w trakcie roku podatkowego, orzekła następująco:

Gdy chodzi o legislację podatkową, to w dotychczasowym orzecznictwie Trybunału Konstytucyjnego wskazywano już, iż nie jest w zasadzie dopuszczalne dokonywanie zmian obciążeń podatkowych w ciągu roku (orzeczenie z 29 marca 1994 r., K. 13/93, OTKw 1994 r., cz. I, s. 49-50). Zmiany takie, gdy chodzi o tzw. „podatki roczne”, zatem również podatek od nieruchomości, powinny wchodzić w życie przed końcem poprzedniego roku podatkowego i to $\mathrm{z}$ odpowiednim vacatio legis (orzeczenie z 28 grudnia1995 r., K. 28/95, OTK ZU Nr 3/1995, s. 204-205). To właśnie brak vacatio legis, a więc czasu na zapoznanie się podatnika ze zmianą niekorzystną dla niego uznał TK za sprzeczny z art. 2 ustawy zasadniczej, zgodnie z którym Rzeczpospolita Polska jest demokratycznym państwem prawnym, urzeczywistniającym zasady sprawiedliwości społecznej [...]. O ile jednostka ma swobodę działania zgodnie z zasadą, że co nie jest wyraźnie zabronione przez prawo, jest dozwolone, to organy władzy publicznej mogą działać tylko tam i tylko o tyle, o ile prawo je do tego upoważnia, przy czym obywatel może zawsze domagać się podani podstawy prawnej, na jakiej organ podjął konkretną działanie. Jest to zgodne $\mathrm{z}$ wymogami wynikającymi z zasady demokratycznego państwa prawnego ${ }^{30}$.

W przedmiotowej sprawie Kolegium Izby wyraźnie wskazało, że takie działanie organu nie odznacza się legalnością w rozumieniu art. 7 Konstytucji RP, a ponadto trudno ustalić na jakiej podstawie prawnej organ oparł swoje rozstrzygnięcie, które godziło w zasadę ochrony praw nabytych, oraz zasadę związania organów władzy publicznej prawem. Jednocześnie

28 https://legnica.skwp.pl/Podatek,od,nieruchomosci,po,nowelizacji,ustawy,Prawo,b udowlane, 12505.html (dostęp: 3.05.2018).

29 http://www.samorzad.lex.pl/czytaj/-/artykul/rada-gminy-moze-podjac-uchwale-o-zwolnieniach-w-podatku-od-nieruchomosci?refererPlid=5267559 (dostęp: 3.05.2018).

${ }^{30}$ Uchwała Regionalnej Izby Obrachunkowej w Zielonej Górze nr 159/09 z dnia 5 sierpnia 2009 r. (Dz.Urz. Lubus 2009 r. Nr 93, poz. 1285). 
uznano, że cofnięcie przedmiotowego zwolnienia w trakcie roku podatkowego niosło za sobą negatywne konsekwencje społeczne poprzez zaskoczenie podatników, znajdujących się w trudnej sytuacji życiowej, byli to bowiem emeryci i renciści powyżej 65 roku życia, którzy samodzielnie prowadzili gospodarstwo domowe. Skutkiem niekorzystnych dla nich zmian, w przypadku wejścia w życie tych regulacji, byłyby zmiany decyzji wymiarowych i opodatkowanie ww. kategorii osób od 1 stycznia 2009 r.

Aby zasady prawidłowej legislacji mogły być realizowane, niezbędne jest założenie o istnieniu racjonalnego ustawodawcy, który zamierza tworzyć przepisy w zgodzie $\mathrm{z}$ tymi zasadami. Jak wyjaśnia J. Zaleśny, fikcja prawna o racjonalności ustawodawcy wymaga przyjęcia, że „wszelkie działania ustawodawcy są efektem dogłębnego rozważenia problemu i dojrzałej decyzji znajdujące racjonalne uzasadnienie”31. „Trudność” w utrzymaniu założenia o racjonalności ustawodawcy w sytuacji funkcjonowania w obecnym kształcie zwolnienia od podatku od nieruchomości gmin. Ustawodawca miał na celu wyeliminowanie negatywnego zjawiska opodatkowania przez gminę siebie samej, co doprowadzało do obniżenia wysokości subwencji wyrównawczej. Tymczasem zgodnie z art. 7 ust. 1 pkt 15 od podatku od nieruchomości zwalnia się grunty i budynki lub ich części, stanowiące własność gminy, z wyjątkiem zajętych na działalność gospodarczą lub będących w posiadaniu innych niż gmina jednostek sektora finansów publicznych oraz pozostałych podmiotów. W konsekwencji, gmina dzierżawiąc od Skarbu Państwa nieruchomość położoną na jej terenie nadal jest podatnikiem i jednocześnie beneficjentem przedmiotowego podatku. Jest to przykład nieracjonalnej legislacji, której, jak oceniają niektórzy autorzy, „nie można uznać za prawidłową choćby nawet spełniała wszelkie formalne kryteria poprawności”32.

5. ZAKOŃCZENIE

Podatek od nieruchomości uregulowany minimalistycznie w 10 artykułach ustawy o podatkach i opłatach lokalnych, jest przykładem maksymalizacji łamania standardów prawidłowej legislacji na tak niewielkiej powierzchni normotwórczej. Nie każde złamanie zasady prawidłowej

${ }^{31} \mathrm{~J}$. Zaleśny, Zasady prawidłowej legislacji.

${ }^{32}$ Tamże; Wyrok TK z 17 maja 2005 r., sygn. P.6/04, OTK ZU nr 5/A/2005, poz. 50, s. 703. 
legislacji na gruncie tegoż podatku można uznać za kwalifikowane, tj. skutkujące uznaniem danego przepisu za niekonstytucyjny, jednakże nie może to stanowić usprawiedliwienia dla zaniechań ustawodawcy w dążeniu do takiego ukształtowania podstawowych elementów konstrukcyjnych podatku, aby były one czytelne i nie tworzyły tak wielu kontrowersji. Art. 217 Konstytucji RP stawia wymóg niezwykłej precyzji dla ustawy podatkowej. W razie jego niespełnienia i powstawania wątpliwości nie dających się usunąć w drodze wykładni powstaje pytanie, czy nadal mamy do czynienia z ustawą podatkową, która w sposób władczy może nakładać obowiązki na podatnika. Jak podnosi T. Dębowska-Romanowska:

Gwarancyjny charakter art. 217 polega na tym, iż ustawa która nie spełnia wprost wymagań kwalifikowanej określoności tekstu ustawy, lub której nieokreśloność jest następstwem niewywiązania się z obowiązku należytego poinformowania każdego o obowiązującym stanie prawnym - nie jest ustawą podatkową. [...] Art. 217 jest bowiem bardzo radykalny w swych rozwiązaniach. Nie ustanawia on materialnych granic opodatkowania, ale za to formułuje bardzo wysokie wymagania kwalifikowanej określoności ustaw podatkowych w relacji do przeciętnej świadomości prawnej adresatów danego obowiązku podatkowego. Chodzi o to, by adresat był w stanie sam bez korzystania z pomocy prawnej lub korzystając z niej tylko tam, gdzie chodzi o podmioty grupowe mające obsługę prawną, mógł ustalić, czy podlega obowiązkowi podatkowemu i w jakiej wysokości podatek poniesie lub poniósłby ${ }^{33}$.

Z drugiej strony, w przypadku podatku lokalnego takie problematyczne ukształtowanie podstawowych elementów konstrukcyjnych powoduje nie tylko zachwianie zaufania obywatela do państwa, ale również zaufania samorządu, który powinien mieć zagwarantowane stabilne źródła dochodowe, aby realizować obligatoryjne zadania własne dla dobra wspólnoty lokalnej. Podatek od nieruchomości z jednej strony, jak wskazywano we wstępie niniejszego artykułu, jest najbardziej dochodowym podatkiem komunalnym, $z$ drugiej strony jego wadliwa konstrukcja a przez to niemożność prawidłowej interpretacji, skutkuje powstawaniem licznych nadpłat w tym podatku. Nie można oczywiście nie zauważyć, że niektóre organy podatkowe w zakresie powyższego podatku wykorzystują wątpliwości interpretacyjne po to by uzyskać jak najwyższą wysokość zobowiązania podatkowego. W celu usunięcia tych patologii, należałoby rozpocząć zmiany $\mathrm{w}$ tym podatku od zastosowania prawidłowych technik legislacyjnych.

${ }^{33}$ T. Dębowska-Romanowska, Opinia na temat przedstawionego przez Prezydenta RP projektu ustawy o zmianie ustawy - Ordynacja podatkowa oraz niektórych innych ustaw (druk nr 3018) z dnia 17 marca 2015 r., s. 2-3. 


\section{BIBLIOGRAFIA}

Brzeziński B., Lasiński-Sulecki K., Morawski W., Relacje terminologiczne ustawy podatkowej i „niepodatkowej” - kazus zwolnienia z podatku od nieruchomości infrastruktury kolejowej, „Przegląd Podatkowy” 2013, nr 5.

Bułajewski S., Zasady prawidłowej legislacji podczas tworzenia aktów prawa miejscowego w Polsce, „Studia Prawnoustrojowe” 2015, nr 29.

Dębowska-Romanowska T., Opinia na temat przedstawionego przez Prezydenta RP projektu ustawy o zmianie ustawy - Ordynacja podatkowa oraz niektórych innych ustaw (druk $n$ r 3018) z dnia 17 marca 2015 r.

Kałążny A., Ruta M., Bocznica kolejowa jako element infrastruktury kolejowej - czy podlega zwolnieniu z podatku od nieruchomości?, „Przegląd Podatkowy” 2018, nr 1.

Mączyński D., Sowiński R., Jasność prawa podatkowego jako warunek poprawnej legislacji podatkowej, „Ruch Prawniczy, Ekonomiczny i Socjologiczny” 2005, z. 3.

Michalska A., Wronkowska S., Zasady tworzenia prawa, Poznań 1983.

Rot H., Ogólne zasady tworzenia prawa PRL, „Studia Prawnicze” 1978, nr 4.

Zaleśny J., Zasady prawidłowej legislacji, „Studia i Analizy” 2009, t. 13.

Wyrok Trybunału Konstytucyjnego z dnia 18 listopada 2014 r. Sygn. akt K 23/12 (Dz.U. z 2014 r., poz. 1663).

Wyrok Trybunału Konstytucyjnego z dnia 13 grudnia 2017 r., sygn. SK 48/15 (Dz.U. z 2017 r., poz. 2432).

Wyrok Wojewódzkiego Sądu Administracyjnego w Białymstoku z dnia 12 września 2013 r. o sygn. akt. II SA/Bk 9/13.

Wyrok Wojewódzkiego Sądu Administracyjnego w Łodzi z 24 czerwca 2013 r., sygn. III SA/Łd 313/13.

Uchwała Naczelnego Sądu Administracyjnego z dnia 3 lutego 2014 r., o sygn. akt: II FPS $11 / 13$.

Uchwała Regionalnej Izby Obrachunkowej w Zielonej Górze nr 159/09 z dnia 5 sierpnia 2009 r. (Dz.Urz. Lubus z 2009 r. Nr 93, poz. 1285).

http://orzeczenia.nsa.gov.pl/doc/B846A5F30B (dostęp: 6.06.2018).

http://podatki.gazetaprawna.pl/artykuly/994969,transport-kolejowy-podatek-od-budynkow-gruntow-infrastruktura-kolejowa.html (dostęp: 6.06.2018).

http://trybunal.gov.pl/postepowanie-i-orzeczenia/komunikaty-prasowe/komunikaty-przed/art/9962-podatki-i-oplaty-lokalne-zasady-ustalania-podatku-od-nieruchomosci/ (dostęp: 3.05.2018).

http://www.rp.pl/Administracja/307059963-Urzednik-nie-rozstrzygnie-kto-jest-spadkobierca-strony-postepowania.html (dostęp: 3.05.2018).

http://www.samorzad.lex.pl/czytaj/-/artykul/rada-gminy-moze-podjac-uchwale-o-zwolnieniach-w-podatku-od-nieruchomosci?refererPlid=5267559 (dostęp: 3.05.2018).

https://ikar.wz.uw.edu.pl/numery/21/pdf/94.pdf (dostęp: 6.06.2018).

https://legnica.skwp.pl/Podatek,od,nieruchomosci,po,nowelizacji,ustawy,Prawo,budowla ne,12505.html (dostęp: 3.05.2018). 
Abstract. The article concerns the issues of complying with standards of good legislation in the legal structure of property tax. The current issue is considered to be of major importance among tax payers and tax authorities.

The consequences of wrong legal regulations of property tax have impact on formation the controversial interpretations in this area. Controversial interpretations may cause a dispute with the tax authority, an application of coercive measures and reduction in icome. Therefore, undertaken theme is particularly important for municipal finanse. It should be noted the property tax is one of the most important source of income in municipal finance system in Poland.

Keywords: property tax, rules of proper legislation, legal structure of property tax, problems in interpretation 